\title{
Problem Based Learning with ICT Based with Learning Creativity to Improve History Learning Achievement
}

\section{Erna Sukestini ${ }^{1 *}$, Achmad Noor Fatirul ${ }^{2}$, Hartono ${ }^{3}$}

${ }^{123}$ Educational Technology Study Program, PGRI Adi Buana University, Indonesia *e-mail: ernasukestini09@gmail.com

\begin{abstract}
Abstrak
Proses pembelajaran yang membosankan membuat partisipasi siswa dalam kegiatan belajar di kelas kurang antusias sehingga dapat membuat prestasi belajar siswa menurun. Tujuan utama penelitian ini adalah untuk menganalisis pengaruh model pembelajaran berbasis masalah TIK dengan kreativitas siswa terhadap prestasi belajar sejarah. Penelitian ini merupakan penelitian eksperimental semu dengan desain faktorial. Sampel penelitian ini adalah XI - IPA 1, XI - IPA 2, XI - IPA 3, dan XI IPA 5 yang masing-masing kelas terdiri dari 34 siswa dan total 170 siswa. Instrumen yang digunakan adalah tes hasil belajar berupa soal pilihan ganda dan tes kreativitas berupa soal uraian. Data pada penelitian ini dianalisis menggunakan statistik inferensial dengan Two Way Anova. Hasil penelitian ini diperoleh F-hitung $=28,908$ dengan nilai signifikansi 0,000 kurang dari 0,05 , diperoleh $F$-hitung $=4,623$ dengan nilai signifikansi 0,033 lebih kecil dari 0,05 , diperoleh F-hitung $=6,060$ dengan a nilai signifikansi 0,015 lebih kecil dari 0,05. Dari hasil penelitian ini dapat diimplikasikan untuk meningkatkan prestasi belajar sejarah, model pembelajaran berbasis masalah dapat digunakan sebagai model alternatif untuk menciptakan lingkungan belajar yang interaktif.
\end{abstract}

Kata kunci: PBL, TIK, prestasi belajar sejarah

\begin{abstract}
The boring teaching and learning process made students participation in the classroom learning activities less enthusiastic that could make students achievement decreased. The main objective of this study was to analyze the effect of the Problem Based Learning model-based ICT with students' creativity on historical learning achievement. This research was a quasi-experimental study with a factorial design. The samples of this study were XI - IPA 1, XI - IPA 2, XI - IPA 3, and XI - IPA 5 and each class consists of 34 students and total 170 students. The instrument used were learning outcome test in the form of multiple-choice questions and creativity test in the form of essay questions. The data on this study were analyzed using inferential statistics with the Two Way Anova. The results of this study obtained F-count $=28,908$ with a significance value of 0,000 less than 0,05 , obtained $F$-count $=4,623$ with a significance value of 0,033 less than 0,05 , the obtained $F$-count $=6,060$ with a significance value of 0,015 less than 0,05. From the result of this study, it can be implied to improve historical learning achievement, problem-based learning models can be used as an alternative model to create an interactive learning environment.
\end{abstract}

Keywords: PBL, ICT, history learning achievement

\section{Pendahuluan}

In this current millennial era, almost all aspects of life cannot be separated from the use of technology, including education. The use of technology on the educational side is important to do to reinforce the teaching and learning process and make the students easier to access information related to the learning materials (Arrosagaray et al., 2019;

\footnotetext{
${ }^{*}$ Corresponding author.

Received 30 Januari 2021; Accepted 1 Maret 2021; Available online 8 April 2021 (C) 2021 MI All Rights Reserved
} 
Hasibuan, 2015). Technology has an important role in the teaching and learning process in schools. The role of technology in the learning process is to make teachers be able to deliver the materials by using computers, LCDs, projectors, active speakers, and also using the internet. The use of technology can increase quality and scope if it is used wisely for education and training, and also it has very important meaning for the welfare (Fernández-Gutiérrez et al., 2020; Gil-Flores et al., 2017).

The use of technology media is applied to all subject matters very well, especially to the materials that tend to only contain theories and sometimes make students feel bored quickly in class. One of the subjects that are considered very supportive if it is integrated with the use of technology is history. History is a subject that convey knowledges, attitudes, and values regarding the process of changes and the development of Indonesian societies and the world from the past to the present (Rosana, 2014; Zahroa, Sumardi, \& Marjono, 2017). Therefore, history is one of the subjects that still being taught at the educational level. However, the fact that happened in the reality, history lessons were boring for the students and even some students did not want to pay attention and ask questions related to the materials. Most teachers did not properly use technology. In teaching and learning activities in schools, teachers tend to use conventional learning models or direct learning without linked the use of the latest technology, so that the learning process looked boring and made students less enthusiastic about the learning process (Herayanti, Habibi, \& Fuaddunazmi, 2017; Wulandari, Sudatha, \& Simamora, 2020). However, if the teachers use an innovative learning model by using technology such as computers, LCDs, and the internet, it will make students be more comfortable and easier to engage the material presented by the teachers, such as in the form of a powerpoint presentation.

This statement is supported by the results of the preliminary research that have been conducted at Public Senior High School of 1 Dawarblandong, especially in class XI IPA, which showed that the students' achievements obtained from learning history are still low. It is shown by the results of the Final Assessment of Semester 2 which showed that $30 \%$ of students who scored above the specified learning completeness criteria were 67 , while $70 \%$ of students scored below the learning completeness criteria. Some students expressed difficulty in understanding the concept of history learning given by the teacher. Based on the results of observations, the learning process at Public Senior High School of 1 Dawarblandong still dominantly used conventional learning models as an introduction to deliver the subject materials in the class, especially in Indonesian history subjects so that the learning situation in the classroom become monotonous and less attractive. This has an impact on the achievement of students' learning outcomes which tend to be low and did not reached the minimum completeness criteria (KKM). Besides, students' creativity also looks low. Equally, the level of students' activity and attention to participate in learning was still low. Based on supervision results from the principal and collaborator teachers, the desire of students in learning Indonesian history to ask questions, answer questions, and their willingness to take notes were also still low even though based on the preliminary result, the class has good skills and score.

The teachers' reason still used the conventional learning model was because many historical materials were presented in a limited time, but the teachers did not realize that the use of this model in history subjects made the learning process less interesting. The students felt that they were listening to a fairy tale which eventually becomes sleepy and falls asleep in class (Diah \& Riyanto, 2016; Winursiti, 2017). The teacher should be evaluated the learning techniques that were used so that students become more active and interested when they learned history subjects. The concept of learning material delivered by the teacher only based on the theories that were taken from books and the teacher did not relate the material concepts to the real-life situation and did not show a direct relationship with the problems that happened in everyday life.

To solve the learning problems, especially the learning achievement and increase the students' creativity, especially in learning the history of the Indonesian language, 
teachers need to design innovative learning technique by using an effective learning model to make students understand the concepts and problem-solving skills of student learning in class so that students be more interested in learning (Kamisa, 2016; Pujiani, Jayusman Jayusman, \& Romadi, 2016). One of learning models that is proper with the provisions of the scientific approach and considered as an effective model for students' problem-solving abilities is Problem Based Learning (PBL). The PBL model is an innovative learning model that can provide active learning conditions for students because the problems are the focus of learning which can be solved by students through groups (Haryati, 2017; Mutakinati, Anwari, \& Yoshisuke, 2018; Ngalimun, 2017)

This statement is in line with the statement by (Mutakinati et al., 2018) which stated that the problem-based learning model is a learning model that focuses students on a problem in the real-life (contextual) environment so that it can improve students' ability to understand concepts and think critically. Problem Based Learning is a learning model that involves students in solving a real problem, which causes the development of students' motivation and curiosity (Sa'diyah, 2020; Gunantara et al., 2014). In general, the advantages of the problem-based learning model are students will get used in facing problems and feel challenged to solve these problems. Besides, students will be accustomed to learn in groups so that learning process did not monotonous and focused on students in learning will be longer because students get to focus on the problem that given by the teachers (Istiningrum, 2017; Marzuki \& Basariah, 2017; Rahayu \& Fahmi, 2018).

However, to maximize learning activities in history subjects in order to get maximum results in the learning process, teachers do not only use innovative learning models which also support the achievement of learning objectives. Teachers also need to integrate learning models with the use of technology that already developed nowadays so that the solutions offered are based on ICT (Information and Communication Technology) (Haviluddin, 2010; Wulandari et al., 2020). The implementation of this study also supports the statement of Permendikbud No. 22 regarding learning at the primary and secondary education levels, which states the lesson plans that are prepared need to look up at the implementation of information and communication technology which is integrated, systematic, and effective manner according to the situations and conditions.

ICT is a component of learning resources that contains teaching materials which based students' environment in the form of information and communication technology. In other words, this media means of distributing information in the form of hardware, software, network, and computer systems as well as telecommunications infrastructure so that the data can be spread and accessed globally (I. M. Dwi, Arif, \& K. Sentot, 2013; Nursamsu \& Kusnafizal, 2017) Therefore, in order to make the learning process by using the PBL model can run optimally, it is necessary to have learning media that implement ICT.

According to Dirckinck-Holmfeld (in Dwi et al., 2013) PBL must be adapted the local conditions, educational goals, and cultural traditions to overcome human resource limitations in using ICT. If PBL based ICT is done well in the learning process it will be able to support students' learning to be successful (Kristinawati et al., 2018; Yassin, 2010). Students will be able to use technology such as computers so that students' creativity can be applied to make a powerpoint or insert the learning material on a video. In improving PBL learning achievement, students can improve their ability and understanding in solving problems so that history learning become fun and not be boring (Diah \& Riyanto, 2016; Umbara, Sujana, \& Negara, 2020).

Researches on the implementation of the Problem Based Learning model-based ICT have been conducted before. Research conducted by (Suwasono \& Puspitasari, 2016) showed that the use of the PBL model based ICT has a positive effect on students' problem in understanding abilities. Then, the same research was also carried out by (Kristinawati et.al., 2018) which showed the results of the use of Problem Based Learning model based ICT is better than using conventional learning models to improve students' 
learning outcomes. From the results of these revelant studies, it can be concluded that the ICT-based PBL learning model has a positive impact.

From the description and problems described above, this study aimed at determine the effect of the Problem Based Learning model-based ICT with the Problem Based Learning Model based non-ICT with learning creativity on history learning achievement in class XI IPA of Public Senior High School 1 Dawarblandong 2019-2020 academic year. Applying the ICT-based PBL learning model is expected to overcome problems related to creativity and learning presences.

\section{Metode}

This research was quasi experimental research. The type of research design used a $2 \times 2$ factorial design. The population in this study were all students of class XI of Public Senior High School 1 Dawarblandong on semester 1 of the 2019/2020 academic year which consist of 5 parallel classes in class XI IPA 1, XI IPA 2, XI IPA 3, XI-IPA 4, and XIIPA 5, and each class consists of 34 students and total 170 students. From this population, the class was taken by cluster sampling. The units sampled were not individual students, but class (clusters) in class XI of Public Senior High School 1 Dawarblandong in the 2019/2020 academic year. Class XI IPA 1 and class XI IPA 3 were the experimental group. Those sample treated by the PBL model were based on ICT and the class groups XI-IPA 2 and XI-IPA 5 were the control classes treated with the PBL model not based on ICT.

The research instrument used in this research was the learning utilizes used in the experimental class and the control class consisted of Student Worksheets (LKS) and Lesson plan. The measurement of the instrument developed consisted of a creativity test of historical learning and historical learning outcomes. The history learning achievement test used to determine students' mastery of the material after participating in the learning process. The learning outcome test was designed in the form of a multiple-choice test with five alternative answer choices.

Before the instrument was used, the instrument validated by an expert. Validation of student worksheets and lesson plans were needed to see the suitability of the learning objectives with the material that students must be mastered after the learning process is over. The instrument in the form of a learning outcome test and a student creativity test was validated by an expert conducted by the head of the MGMP history. After the instrument was validated based on expert judgment, then the item validation was carried out by empirical instrument testing.

The data used in this study were test value data which obtained through learning outcomes tests and student learning creativity tests. Before testing the hypothesis and testing the prerequisites for the analysis, namely the normality test and the homogeneity test, the initial similarity test of the samples used is carried out first. After the prerequisite test was conducted, the research hypothesis was tested using Two-Way Anova. Hypothesis testing was used to test the differences in creativity between the experimental class and the control class, test the differences in creativity between students who had high and low creativity, and saw the effect of the interaction of learning models (PBL models-based ICT) and learning creativity on learning achievement. Hypothesis testing was done with the help of the statistical program SPSS 25 for windows.

\section{Hasil dan Pembahasan}

In this study, the data on students' History Learning Achievement were obtained from the History Learning Achievement test which was carried out after receiving learning treatment, so that the results of the average value of History Learning Achievement by learning using ICT-based PBL were obtained amounted to 78,52 and the average value of 
achievement in learning History with PBL without ICT is 72,05 . In this study, the data on student creativity obtained from learning creativity were presented as follows:

Table 1. Description of Student creativity is taught using PBL based ICT

\begin{tabular}{lcc}
\hline $\begin{array}{l}\text { Learning Creativity } \\
\text { Using Problem Based } \\
\text { Learning based ICT }\end{array}$ & Frequency & Percentage \\
\hline Low student creativity & & \\
High student creativity & 21 & 30,9 \\
Total & 47 & 69,1 \\
\hline
\end{tabular}

So, from the table above it can be stated that from the 68 students there were 47 students $(69,1 \%)$ who had high creativity results, 21 students $(30,9 \%)$ have low creativity.

Table 2. Description of Student creativity is taught using PBL without ICT

\begin{tabular}{ccc}
\hline $\begin{array}{c}\text { Learning } \\
\text { Creativity Using Problem Based } \\
\text { Learning based ICT }\end{array}$ & Frequency & Percentage \\
\hline Low student creativity & 29 & 42,6 \\
High student creativity & 39 & 57,4 \\
\hline Total & $\mathbf{6 8}$ & $\mathbf{1 0 0 , 0}$ \\
\hline
\end{tabular}

Thus, it can be stated that from the 68 students there were 39 students $(57,4 \%)$ who had high creativity results, 29 students $(42,6 \%)$ have low creativity. The results of the two-way Anava test from the creativity table above are described as follows:

Two Path test results obtained Fcount $=28,908$ with a significance value of 0,000 less than 0,05 . This result means that the null hypothesis $(\mathrm{Ho})$ is rejected, which means that the learning achievement of the group of students who learned through the PBL model and the group of students taught through the PBL model based on the different ICT. It can also be explained that there were significant differences in the learning achievement of groups of students who are taught through the PBL model not based on ICT and groups of students who are taught through the PBL model with ICT-based.

Two Path Anava test results obtained Fcount $=4.623$ with a significance value of 0.033 less than 0.05 . This result means that the null hypothesis $(\mathrm{Ho})$ is rejected, meaning that the learning outcomes of groups of students who had high creativity and groups of students who had low creativity were different. It can also be explained that there were significant differences in the learning outcomes of students who had high creativity and groups of students who had low creativity.

The results of the Anava Two Path test in Table 4 showed that the value of Fcount $=6,060$ with a significance value of 0,015 was less than 0,05 . These results can be interpreted that the null hypothesis $(\mathrm{H} 0)$ is rejected, which means there was an influence of the interaction of learning models (PBL models and PBL models-based ICT) and student creativity on learning achievement.

Based on the first hypothesis, the results obtained was the learning achievement of groups of students who learned through PBL models and groups of students taught through PBL models based on ICT was different. It can also be explained that there were significant differences in the learning achievement of groups of students who were taught through the PBL model not based on ICT and groups of students who were taught through the PBL model with ICT-based. This is because a conducive learning environment also able to stimulate students' motivation. The motivational factor will foster positive beliefs about their ability to complete the task which will help to improve students' understanding (Wu \& Wu, 2020; Wulandari \& Surjono, 2013). So that, the ICT assistance provided did not only have an impact on students 'knowledge and skills, but can also motivate and 
increase students' confidence when solving problems with various kinds of solutions. The PBL model also capable to create peer interactions during the investigation process. Students who were taught using PBL only get help from peers, but did not get help (scaffold) from ICT (Rajagukguk \& Simanjuntak, 2015; Rudiyati, 2013). There is a weakness in peer feedback in the investigation process due to the absence of scaffold in the peer feedback interaction process (Seng \& Hill, 2014)

Based on the second hypothesis, the results obtained from the learning outcomes of groups of students who had high creativity and groups of students who had low creativity were different. This is because students who have creativity will find it easy to solve the problems that they found in the learning process. In the learning process, students will find problems and difficulties in the form of questions that require creativity in solving the problems (Hartini, Kusdiwelirawan, \& Fitriana, 2014; Putri, Munzir, \& Abidin, 2019). Students who have creativity will be more transfer knowledge easily to gain new knowledge and apply historical concepts to the problems that require variations in answering and propose new ideas. Students should be equipped with the skills needed to be creative in solving the problems that they faced (Suprapto et al., 2018; Gunawan et al., 2017). PBL based ICT will increase students' creativity because the PBL model is a learning model that is carried out by challenging students with problems that existed in students' daily real life so that students can construct their own knowledge in solving problems that they faced and encourage students to think creatively. The ability to think creatively has characteristics such as coming up with many ideas, answers, solving problems or questions, providing many ways or suggestions for doing various things (Rohana \& Wahyudin, 2017). The ability to think creatively is needed to support the learning process so that it will have a positive influence on learning outcomes.

Based on the third hypothesis, the results obtained that there was an influence of the interaction of learning models (ICT-based PBL) and students' creativity on learning achievement. This is because the PBL model which is integrated with ICT make learning activities more interesting and less boring because it cannot be denied that students are currently more interested in seeing electronic properties rather than viewing textbooks. Interesting learning will make students not be bored in participating in the learning activities because interesting learning will eliminate monotony and boredom in students (Athanases, Sanchez, \& Martin, 2020; Roling et al., 2020). In the learning process this PBL model integrated with ICT so that it is interesting and does not make students feel bored. Students are also more interested in paying attention to the material and making it easier for them to understand aboutwhat has been received so that it will have a positive effect on student's achievement. PBL model will make students to be more creative. Creativity is the ability to initiate ideas, see new or unexpected relationships, the ability to formulate concepts that is not only just memorize, but also create new answers to the existing problems, and get new questions that is needed to be answered (Rohana \& Wahyudin, 2017; Gunawan et al., 2017). PBL model make students be more creative because students are trained to be able to solve problems that they faced with creative solutions from students' thinking. ICT is a media that make students interested and be enthusiastic in following the learning process so that students will be pay more attention to the learning process maximally (Arrosagaray et al., 2019). PBL model which is based by ICT will make students even more enthusiastic in participating in the learning process so that it will affect student creativity and learning outcomes.

The results of this study also supported by research conducted by (FernándezGutiérrez et al., 2020) that stated the use of ICT in schools autonomously has a positive effect on PISA scores in mathematics and reading and a positive effect on PISA scores in science thus suggesting that the impact of ICT on educational outcomes depends on the subject and type of technology use. Then the research conducted by (Nuswowati, Susilaningsih, Ramlawati, \& Kadarwati, 2017) stated that the implementation of the Problem Based Learning (PBL) model with green chemistry insight can improve students' 
creative thinking skills and creative action. So, it can be denied that the PBL model has a positive effect on student learning outcomes.

Based on these results, new findings in this study are that the PBL model-based ICT has a positive effect on student achievement. The PBL model is a learning approach that emphasizes the scientific learning where students are required to actively get concepts by solving problems (Serevina et.al., 2018). Through the problems presented by the teacher, students'creativity will be more developed and students will be more eager to participate in learning activities so that it has an impact on increased student learning achievement. The contribution of research results in the scientific field can be used as a reference or consideration for the implementation of learning activities in class

\section{Simpulan}

Based on the general description, hypothesis testing and discussion, it can be concluded that there is a significant difference between the learning achievement of the group of students taught using PBL model- based ICT and the group of students taught using PBL model not based on ICT in class XI IPA students of Public Senior High School 1 Dawarblandong. The PBL model-based ICT also affects the interaction of learning models and students' creativity on history learning achievement of students in class XI IPA at Public Senior High School 1 Dawarblandong.

\section{Daftar Pustaka}

Arrosagaray, M., González-Peiteado, M., Pino-Juste, M., \& Rodríguez-López, B. (2019). A comparative study of Spanish adult students' attitudes to ICT in classroom, blended and distance language learning modes. Computers and Education, 134(October 2018), 31-40. https://doi.org/10.1016/j.compedu.2019.01.016

Athanases, S. Z., Sanchez, S. L., \& Martin, L. M. (2020). Saturate, situate, synthesize: Fostering preservice teachers' conceptual and practical knowledge for learning to lead class discussion. Teaching and Teacher Education, 88, 102970. https://doi.org/10.1016/j.tate.2019.102970

Diah, \& Riyanto. (2016). Problem-Based Learning Model In Biology Education Courses To Develop Inquiry Teaching Competency Of Preservice Teachers. Cakrawala Pendidikan, 35(1), 47-57. https://doi.org/https://doi.org/10.21831/cp.v1i1.8364

Dwi, I. M., Arif, H., \& Sentot, K. (2013). Pengaruh strategi problem based learning berbasis ICT terhadap pemahaman konsep dan kemampuan pemecahan masalah fisika. Jurnal Pendidikan Fisika Indonesia, 9(1), 8-17. https://doi.org/10.15294/jpfi.v9i1.2575

Fernández-Gutiérrez, M., Gimenez, G., \& Calero, J. (2020). Is the use of ICT in education leading to higher student outcomes? Analysis from the Spanish Autonomous Communities. Computers and Education, 157, 103969. https://doi.org/10.1016/j.compedu.2020.103969

Gil-Flores, J., Rodríguez-Santero, J., \& Torres-Gordillo, J. J. (2017). Factors that explain the use of ICT in secondary-education classrooms: The role of teacher characteristics and school infrastructure. Computers in Human Behavior, 68, 441449. https://doi.org/10.1016/j.chb.2016.11.057

Gunantara, G., Suarjana, M., \& Riastini, P. N. (2014). Penerapan model pembelajaran problem based learning untuk meningkatkan kemampuan pemecahan masalah matematika siswa kelas V. Jurnal Mimbar PGSD Undiiksha, 2(1). https://doi.org/http://dx.doi.org/10.23887/jjpgsd.v2i1.2058

Gunawan, G., Sahidu, H., Harjono, A., \& Suranti, N. M. Y. (2017). The effect of project 
based learning with virtual media assistance on student's creativity in physics. Jurnal Cakrawala Pendidikan, (2).

Hartini, T. I., Kusdiwelirawan, \& Fitriana, I. (2014). Pengaruh Berpikir Kreatif dengan Model Problem Based Learning (PBL) Terhadap Prestasi Belajar Fisika Siswa dengan Menggunakan Tes Open Ended. PII 3 (1). Jurnal Pendidikan IPA Indonesia, 3(1), 8-11. https://doi.org/https://doi.org/10.15294/jpii.v3i1.2902

Haryati, Y. (2017). Model Problem Based Learning Membangun Kemampuan Berpikir Kritis Siswa Sekolah Dasar. Jurnal Cakrawala Pendas, 3(2), 57-63. https://doi.org/http://dx.doi.org/10.31949/jcp.v3i2.596

Hasibuan, N. (2015). Pengembangan pendidikan Islam dengan implikasi teknologi Pp. FITRAH:Jurnal Kajian Keislaman, 1/(2). https://doi.org/10.24952/fitrah.v1i2.313

Haviluddin. (2010). Active Learning berbasis Teknologi Informasi (ICT). Jurnal IImiah IImu Komputer, 5(3). https://doi.org/http://dx.doi.org/10.30872/jim.v5i3.64.

Herayanti, L., Habibi, H., \& Fuaddunazmi, M. (2017). Pengembangan Media Pembelajaran Berbasis Moodle pada Matakuliah Fisika Dasar. Jurnal Cakrawala Pendidikan, 36(2), 210-219. https://doi.org/10.21831/cp.v36i2.13077

I. M. Dwi, Arif, H., \& K. Sentot. (2013). Pengaruh Strategi Problem Based Learning Berbasis ICT Terhadap Pemecahan Konsep dan Kemampuan Pemecahan Masalah Fisika. Jurnal Pendidikan Fisika Indonesia, 9(1). https://doi.org/https://doi.org/10.15294/jpfi.v9i1.2575

Istiningrum, A. A. (2017). Peningkatan Self-Regulated Learning Skills Mahasiswa Pada Mata Kuliah Akuntansi Pengantar Melalui Problem-Based Learning. Cakrawala Pendidikan, 36(1), 81-91. https://doi.org/https://journal.uny.ac.id/index.php/cp/article/view/11080/pdf.

Kamisa, A. (2016). Penerapan Model Problem Based Learning Dalam Pembelajaran Sejarah Untuk Meningkatkan Motivasi Dan Prestasi Belajar Siswa Kelas XI IPS 1 Sman 1 Butar Sulawesi Tengah. Jurnal Pendidikan Dan Sejarah, 12(1). https://doi.org/https://doi.org/10.21831/istoria.v12i1.9542

Kristinawati, \& Dkk. (2018). ICT Based-Problem Based Learning on Students' Cognitive Learning Outcomes. Jurnal Pendidikan Sains, 6(2), 38-42. https://doi.org/http://dx.doi.org/10.17977/jps.v6i2.11683

Kristinawati, E., Susilo, H., \& Gofur, A. (2018). ICT Based-Problem Based Learning on Students' Cognitive Learning Outcomes. Jurnal Pendidikan Sains, 6(2), 38-42. https://doi.org/http://dx.doi.org/10.17977/jps.v6i2.11683

Listiani, N. M. (2014). Pengaruh kreativitas dan motivasi terhadap hasil belajar mata pelajaran produktif pemasaran pada siswa kelas XI SMK Negeri 2 Tuban. Jurnal Ekonomi Pendidikan Kan Kewirausahaan, 2(2). https://doi.org/10.1017/CBO9781107415324.004

Marzuki, \& Basariah. (2017). The Influence Of Problem-Based Learning And Project Citizen Model In The Civic Education Learning On Student'scritical Thinking Ability And Self Discipline. Cakrawala Pendidikan, 6(3), 382-400. Retrieved from https://journal.uny.ac.id/index.php/cp/article/view/14675/pdf.

Mutakinati, L., Anwari, I., \& Yoshisuke, K. (2018). Analysis of students' critical thinking skill of middle school through stem education project-based learning. Jurnal Pendidikan IPA Indonesia, 7(1), 54-65. https://doi.org/10.15294/jpii.v7i1.10495

Ngalimun. (2017). Strategi Pembelajaran dilengkapi dengan 65 Model Pembelajaran. Yogjakarta: Parama IImu. 
Nursamsu, N., \& Kusnafizal, T. (2017). Pemanfaatan Media Pembelajaran Ict Sebagai Kegiatan Pembelajaran Siswa Di Smp Negeri Aceh Tamiang. Jurnal IPA \& Pembelajaran IPA, 1(2), 165-170. https://doi.org/10.24815/jipi.v1i2.9691

Nuswowati, M., Susilaningsih, E., Ramlawati, \& Kadarwati, S. (2017). Implementation of problem-based learning with green chemistry vision to improve creative thinking skill and students' creative actions. Jurnal Pendidikan IPA Indonesia, 6(2), 221228. https://doi.org/10.15294/jpii.v6i2.9467

Pujiani, Jayusman Jayusman, \& Romadi, R. (2016). Eksperimen Model Problem Based Learning dalam Pembelajaran Sejarah Terhadap Hasil Belajar Sejarah Siswa Kelas XI SMA N 1 Pejagoan Tahun Pelajaran 2015/2016. Indonesian Journal of History Education, 4(2). Retrieved from https://journal.unnes.ac.id/sju/index.php/ijhe/article/view/18097

Putri, C. A., Munzir, S., \& Abidin, Z. (2019). Kemampuan Berpikir Kreatif Matematis Siswa melalui Model Pembelajaran Brain-Based Learning. Jurnal Didaktik Matematika Universitas Syiah Kuala, 6(1), 12-27. https://doi.org/10.24815/jdm.v6i1.9608

Rahayu, E., \& Fahmi, S. (2018). Efektivitas penggunaan model problem based Learning (PBL) dan inkuiri terhadap hasil belajar matematika siswa SMP N 1 Kasihan Kabupaten Bantul semester genap tahun ajaran 2017/2018. JURING (Journal for $\begin{array}{llll}\text { Research in } \quad \text { Mathematics Learning), } & 147 .\end{array}$ https://doi.org/10.24014/juring.v1i2.5671

Rajagukguk, \& Simanjuntak. (2015). Problem-Based Mathematics Teaching Kitsintegrated With Ict To Improvestudents' Critical Thinking Ability Injunior High Schools In Cakrawala Pendidikan, 34(3). https://doi.org/https://journal.uny.ac.id/index.php/cp/article/view/7342/pdf

Rohana, R., \& Wahyudin, D. (2017). Project based learning untuk meningkatkan berpikir kreatif siswa SD pada materi makanan dan kesehatan. Jurnal Penelitian Pendidikan, 16(3), 235-243.

Roling, G., Lutz, G., Edelhäuser, F., Hofmann, M., Valk-Draad, M. P., Wack, C., ... Scheffer, C. (2020). Empathy, well-being and stressful experiences in the clinical learning environment. Patient Education and Counseling, (2019). https://doi.org/10.1016/j.pec.2020.04.025

Rosana. (2014). Pengaruh Metode Pembelajaran dan Kemampuan Berpikir Kritis Terhadap Hasil Belajar Sejarah Siswa. Jurnal Pendidikan Sejarah, 3(1), 34-44. https://doi.org/http://dx.doi.org/10.30870/candrasangkala.v1i1.746

Rudiyati, S. (2013). Peningkatan Kompetensi Guru Sekolah Inklusif Dalam Penanganan Anak Berkebutuhan Pendidikan Khusus Melalui Pembelajaran Kolaboratif. Cakrawala Pendidikan, 1(2). https://doi.org/https://doi.org/10.21831/cp.v0i2.1488

Sa'diyah, S. (2020). Peningkatan motivasi dan hasil belajar sistem gerak melalui model pembelajaran problem based learning. Journal of Curriculum Indonesia, 3(2), 79. https://doi.org/10.46680/jci.v3i2.32

Seng, \& Hill. (2014). Using a Dialogical Approach to examine Peer feedback During Chemidtry Investigative Task Discussion. Res Science Education, 44, 727-749.

Serevina, Sunaryo, Raihanati, Sari, \& Juwita. (2018). Development of E-module Based on Problem Based Learning (PBL) on Heat and Temperature to Improve Student's Science Process Skill". Turkish Online Journal of Educational Technology-TOJET, 17(3), 26-36. Retrieved from https://eric.ed.gov/?id=EJ1184205

Suprapto, P. K., bin Ahmad, M. Z., Chaidir, D. M., Ardiansyah, R., \& Diella, D. (2018). Spatial intelligence and students' achievement to support creativity on visuospatial- 
based learning. Jurnal Pendidikan IPA Indonesia, 7(2), 224-231. https://doi.org/10.15294/jpii.v7i2.14322

Suwasono, \& Puspitasari, E. (2016). Pengaruh Problem Based Learning Berbantuan ICT terhadap Kemampuan Pemecahan Masalah Mahasiswa Pendidikan Fisika Angkatan Tahun 2016/2017 pada Materi Fluida Statis. Jurnal Riset Pendidikan Fisika, 1(1), 28-32.

Umbara, I. A. A. P., Sujana, I. W., \& Negara, I. G. A. O. (2020). Model Pembelajaran Problem Based Learning Berbantuan Media Gambar Seri BerpengaruhTerhadap Kompetensi Pengetahuan IPS Siswa. Jurnal Mimbar IImu, 25(2), 174-186. https://doi.org/http://dx.doi.org/10.23887/mi.v25i2.25154

Winursiti. (2017). Penerapan Model Problem Based Learning Berbantuan Reinforcement Simbolik Untuk Meningkatkan Motivasi Dan Hasil Belajar Matematika Siswa Kelas IVB di SD Lab Undiksha. Jurnal IImiah Sekolah Dasar, 17(2), 270-275. https://doi.org/http://dx.doi.org/10.23887/jisd.v1i4.12120

Wu, T. T., \& Wu, Y. T. (2020). Applying project-based learning and SCAMPER teaching strategies in engineering education to explore the influence of creativity on cognition, personal motivation, and personality traits. Thinking Skills and Creativity, 35(January), 100631. https://doi.org/10.1016/j.tsc.2020.100631

Wulandari, Sudatha, \& Simamora. (2020). Pengembangan Pembelajaran Blended Pada Mata Kuliah Ahara Yoga Semester II di IHDN Denpasar. Jurnal Edutech Undiksha, 8(1), 1-15. https://doi.org/http://dx.doi.org/10.23887/jeu.v8i1.26459

Wulandari, \& Surjono, H. D. (2013). Pengaruh Problem-Based Learning Terhadap Hasil Belajar ditinjau dari Motivasi Belajar PLC di SMK. Jurnal Pendidikan Vokasi, 3(2). https://doi.org/https://doi.org/10.21831/jpv.v3i2.1600

Yassin, S. F. (2010). Interdiscipinary Intergration Trough Problem Based Learning With ICT in Pre-Service Teacher Education. Proceedings of EABR Dan ETLC Converence, Dublin, Ireland, 377-385.

Zahroa, Sumardi, \& Marjono. (2017). The Implementation Of The Character Education In History Teaching. Jurnal Historica, 1(1), 1-11. 